\title{
Kyberantropologie a kyberkultura
}

\author{
Václav Soukup \\ Katedra teorie kultury (kulturologie) Filozofické fakulty Univerzity Karlovy v Praze, Celetná 20, 11000 Praha 1
}

\author{
CYBERANTHROPOLOGY AND CYBERCULTURE
}

ABSTRACT The aim of this paper is to provide an account and analysis of Cyberanthropology as a relatively new anthropologic discipline. The subject of cyberanthropologic research is (1) Location where the new information and communication technologies are created; (2) Cyberspace where the information is bestowed; and (3) Shared way of life of information systems users. The stimulus, which lead to the inception of Cyberanthropology, was the growing influence of modern communication technologies on the common way of life. Socio-cultural anthrpologists realized that the new information technologies as well as the scientific knowledge in the area of media communication more and more influence the existence of social, economical and political systems. Furthermore, they wipe down the frontiers between people and machines and create a new type of virtual reality - cyberspace and cyberculture. Consequently, the necessity to describe, analyse and interpret this cultural phenomenon resulted in a birth of a new field of Sociocultural Anthropology - Cyberanthropology.

KEY WORDS culture; cyberculture; cyberspace; cyberpunk; cyberanthropology

ABSTRAKT Cílem studie je teoretická deskripce a analýza kyberantropologie jako relativně nové antropologické disciplíny. Předmětem výzkumů kyberantropologie jsou (1) místa, kde jsou nové informační a komunikační technologie vytvářeny, (2) kyberprostor, v němž jsou informace umístěny a (3) sdílený způsob života uživatelů informačních systémů. Stimulem, který vedl ke vzniku kyberantropologie, byl prudce rostoucí vliv moderních komunikačních technologií na způsob života stále většího počtu obyvatel naší planety. Sociokulturní antropologové si uvědomili, že nové informační technologie, stejně jako vědecké poznatky v oblasti mediální komunikace, stále více ovlivňují fungování sociálních, ekonomických a politických systémů, stírají dřive nezpochybnitelné hranice mezi lidmi a stroji a vytvářejí nový typ virtuální reality - kyberprostor a kyberkulturu. Snaha antropologů popsat, analyzovat a interpretovat tento nový kulturní fenomén vedla ve svých důsledcích ke zrození nové tematické oblasti a subdisciplíny sociokulturní antropologie - kyberantropologie.

KLÍČOVÁ SLOVA kutura; kyberkultura; kyberprostor; kyberpunk; kyberantropologie

\section{KULTURA JAKO PŘEDMĚT VÝZKUMŮ KYBERANTROPOLOGIE}

Kyberantropologie („cyberanthropology“) představuje relativně novou oblast antropologických výzkumů, která se zabývá studiem člověka a proměn lidské interakce v kontextu moderních počítačových, informačních a komunikačních technologií. Předmětem kyberantropologie je zejména analýza a interpretace kulturně utvářených sítí informací a sdílených významů, jež jako specifický typ virtuální reality vznikají v průběhu interakce uživatelů kybernetických systémů (Miller - Slater 2000, Rheingold 1991, 1994, Shields 1996, Schroeder 1996). Zrození kyberantropologie je spjato se zájmem někte- rých antropologů o studium moderních technologií, zejména toho, jak jsou vytvářeny a uváděny do společností s odlišným kulturním kontextem.

Zásadním stimulem, jenž obrátil pozornost antropologů ke studiu moderních technologií a komunikačních sítí, byla expanze internetu, který propojil miliony počítačů a jejich uživatelů. Prostřednictvím internetu lidé vstoupili do kyberprostoru, kde začali vytvářet diferencované zájmové skupiny, vykazující rysy subkultury.

Tyto virtuální komunity, sdílející specifické vzorce chování a myšlení a disponující vlastním jazykem, vytvořily rozsáhlé sociální pole, jež umožňuje realizovat antropologický výzkum. Předmětem antropologického studia zde mohou být 
například rozmanité vztahy mezi jazykem, sociální strukturou a kulturní identitou, které vznikají jako důsledek komunikace zprostředkované počítači. Za další významnou tematickou oblast lze označit "politickou ekonomii kyberkultury“, která zahrnuje vztahy mezi informacemi a různými typy kapitálu. Předmětem výzkumu vedeného $z$ této perspektivy mohou být např́klad politické a ekonomické vztahy mezi rozvinutými a rozvojovými zeměmi v kontextu informačních a komunikačních technologií. Narůstající zájem antropologů o tyto problémové okruhy vyústil v devadesátých letech 20 . století ve zrození nové antropologické subdisciplíny - kyberantropologie.

Základy kyberantropologie položil v roce 1994 americký antropolog Arturo Escobar v článku Welcome to Cyberia: Notes on the Anthropology of Cyberculture (Vítejte v Kybérii: Poznámky k antropologii kyberkultury). Escobar uvedl do antropologie pojem kyberkultura, aby jeho prostřednictvím analyzoval základní strukturální proměny moderní společnosti, které ve druhé polovině 20 . století vyvolaly nové technologie (Escobar 1994, 211-232). Podle Escobara lidé stále více žijí a utvářejí své osobnosti $\mathrm{v}$ technokulturním prostředí informačních technologií a biotechnologií. Informační technologie vedou podle jeho názoru k rozvoji „technosociality“, biotechnologie naopak vyvolávají „biosocialitu“ (Escobar 1994, 214). Escobar je přesvědčen, že antropologie je vhodná pro popis a kulturní diagnózu sociokulturních procesů, jež v současném světě vyvolaly vědecko-technické vynálezy. Proto za hlavní cíl rodící se kyberantropologie označil „etnografické studium hranic mezi lidmi a stroji, které jsou specifické pro společnosti pozdního 20. století" (Escobar 1994, 216). Escobar vymezil výzkumné pole kyberantropologie prostřednictvím následujících otázek:

1. Jaké jsou diskurzy a praktiky tvořené technologiemi a kolem počítačů? Které oblasti lidských aktivit tvoří tento diskurz a praktiky? Jak jsou umístěny v síti sociálních institucí, hodnot a konvencí? Jaké nové formy sociálních konstrukcí reality představují technologie?

2. Jak mohou být tyto domény a praktiky antropologicky studovány v rozdílných geografických a etnických souborech? Které starší antropologické koncepty a metody mohou být při studiu kyberkultury použity? Jak budou naše představy o komunitě, identitě a subjektu transformovány?

3. Jaké je pozadí porozumění, z něhož nové technologie vycházejí? Které moderní praktiky v oblastech života, práce a jazyka utvářejí současné porozumění, design a módy nových technologií? Jak nové technologie pronikají do nezápadních kultur a ovlivňují jejich existenci?

4. Jaká je politická ekonomie kyberkultury? Jakým způsobem jsou přestrukturovány vztahy mezi prvním a třetím světem? Která nová rozdělení se objevila s globálním kapitálem založeným na této technologii?

Escobar zásadním způsobem přispěl $\mathrm{k}$ tomu, že předmětem antropologických výzkumů se stala kyberkultura. Tu lze z antropologické perspektivy vymezit jako součást kulturní praxe a životního stylu spojeného s využíváním moderních informačních a komunikačních technologií. Kyberkultura může být studována prostřednictvím kulturních idejí, rituálů a společenských vztahů, které vznikají v kyberprostoru, a hodnot, norem a institucí, jež virtuální realita vytváří a podporuje. Ohniskem kyberkultury jsou především diskurzy a kulturní praktiky spojené s využíváním informačních a komunikačních technologií. Mezi preferovaná témata kyberantropologického výzkumu patří:

1. Produkce a využívání nových informačních a komunikačních technologií jako nástrojů antropologické výuky a výzkumu.

2. Vliv vědy a informačních technologií na představivost, estetické technonarace a technoliterární praktiky vznikající v kyberprostoru.

3. Kyberkulturní texty (literatura, hudba, film, videohry) a komunikace zprostředkovaná počítačem a internetem.

4. Vztah mezi internetovou komunikací, sociální strukturou a kulturní identitou.

5. Komunity založené na využívání počítačů a internetové infrastruktury.

6. Tok informací a informačních kategorií v lokálním i globálním kontextu.

7. Informační kapitalismus a politická ekonomie kyberkultury.

8. Kyberpunk a jeho vliv na životní styl v době postmoderny (Thomas 1991, 33).

Obecně lze konstatovat, že hlavním cílem kyberantropologických výzkumů je přispět k pochopení diskurzů a praktik uživatelů počítačů a informačních technologií, analyzovat vztah mezi reálným prostorem a kyberprostorem a interpretovat fenomén kyberkultury jako specifický životní styl sdílený a předávaný př́slušníky různých typů internetových subkultur.

Originálním způsobem přispěl k vymezení kyberkultury antropolog David Bell ve své práci An Introduction to Cyberculture (Úvod do kyberkultury, 2001), ve které se zamýšlí nad vztahem mezi kyberprostorem, každodenností a naracemi. Podle Bella „počítače nedávají pouze podobu metaforám, ale jsou jimi také utvářeny“ (Bell 2001, 3). Svět narací, vystupující v podobě př́běhů a vyprávění, má pro antropologii zásadní význam. Prostřednictvím prŕběhů totiž lidé dávají význam světu, který je obklopuje, a vymezují smysl své existence.

Proto je podle Bella důležité „redefinovat kyberprostor v kontextu každého vyprávění a poté prozkoumat překrytí a průsečíky těchto definic“ (Bell 2001, 7). Bell je přesvědčen, že příb̌̌hy na téma moderních informačních technologií, jež fatálně ovlivňují lidské životy, je možné rozdělit na tři skupiny podle následujících kritérií - co jsou, co znamenají a co dělají. Z tohoto hlediska podstatu kyberkultury tvoří tři prameny vyprávění:

1. Př́běhy spjaté s materiální bází kyberkultury a dějinami komunikačních technologií.

2. Příběhy založené na vlastní zkušenosti s tím, jak kyberprostor utváŕí a formuje naše zážitky, kulturní praktiky a každodenní život.

3. Příběhy symbolické, vyrůstající z představ a vyprávění na téma Co pro nás mohou technologie udělat nebo co budou dělat. 


\section{VZNIK A VÝVOJOVÉ PROMĚNY KYBERKULTURY}

Fenomén kyberkultury se zrodil v průběhu šedesátých a sedmdesátých let 20. století jako sekundární produkt vývoje počítačủ a interaktivních komunikačních technologií. Mezi první reprezentanty tohoto specifického typu subkultury lze zařadit počítačové vědce, programátory, vysokoškolské učitele a studenty, kteří sdíleli víru v kladný potenciál počítačů a neomezené možnosti informačních technologií jako prostředku svobodného prístupu a širrení dat a informací. V sedmdesátých letech prrekročily počítačové technologie hranice vědeckých ústavů a univerzit.

Podíl na této expanzi měl technologický pokrok spojený se vznikem prvního, mikroprocesoru Intel 4004 (1971) a vytvoření prvního osobního počítače Altair 8800 (1974). V roce 1975 byla založena budoucí softwarová a počítačová velmoc - společnost Microsoft. V roce 1977 uvedla firma Apple Computer na trh první sériově vyráběný mikropočítač Apple II a zahájila tak průlom digitálních technologií do veřejné i osobní sféry člověka.

Paralelně se zdokonalováním počítačových technologií se vyvíjela hackerská komunita, vyžadující volný př́stup k počítačům, svobodný tok informací a decentralizaci. Sdílenou životní filozofií subkultury hackerů byl předpoklad, že počítače mohou učinit život lepším a že jejich prostřednictvím lze tvořit umění a krásu. $\mathrm{V}$ osmdesátých letech se ve vyspělých západních zemích počítače a veřejné počítačové sítě staly již běžnou součástí kanceláří a prostředkem domácí zábavy. To ve svých důsledcích vedlo $\mathrm{k}$ rozmachu virtuálních subkultur, sdružujících různé typy počítačových hráčů. Současně došlo $\mathrm{k}$ diferenciaci hackerských komunit a vzniku literárních a uměleckých hnutí inspirovaných počítačovými technologiemi, jako je např́íklad kyberpunk („,cyberpunk“), který se v první polovině osmdesátých let oddělil od klasické science fiction. Součástí kyberkulturní scény se stala také nová generace hackerů - tzv. crackerů, která se profilovala jako specifický typ kontrakultury.

Crackeři začali kromě vývoje volného softwaru programově nabourávat zabezpečení lokálních sítí a prolamovat ochranu placených počítačových programů.

Přestože se předcházející generace hackerů od tohoto typu počítačové kriminality distancovala, crackeři se považovali za jejich pokračovatele. Změnu v hodnotovém a normativním systému crackerské kontrakultury ale ilustrují jejich programová prohlášení typu „bojuj s mocí, „vrat šum do systému“ nebo „udělej to sám“. Nástup této počítačové kontrakultury se negativně odrazil v užívání slova hacker, které se stalo synonymem deviantního a kriminálního chování v kyberprostoru.

Kvalitativní skok v budování kyberprostoru znamenal rok 1989, kdy Angličan Tim Berners-Lee zpracoval rozsáhlou hypertextovou databázi vědců pro potřeby Evropské organizace pro jaderný výzkum (CERN) a krátce poté v roce 1990 vytvořil všechny nezbytné nástroje umožňující fungování webu - http (,hypertext transfer protocol“), html (,hypertext markup language“) a textový prohližeč nazvaný „World Wide Web“, jenž uživatelům umožňoval nejen stránky prohlížet, ale i editovat.
V roce 1991 se již objevují osobní stránky, chat a diskusní skupiny. $\mathrm{V}$ devadesátých letech pokračoval masový nárůst uživatelů počítačů a internetu. Standardizace hardwaru po vzoru IBM a expanze velkých společností, jako jsou Microsoft a Apple, byla doprovázena sjednocováním standardů, ceny a výkonu osobních počítačů.

$\mathrm{K}$ masovému růstu kyberkultury $\mathrm{v}$ tomto období přispěl také technologický vývoj směřující $\mathrm{k}$ zjednodušení uživatelského prostředí, grafického rozhraní počítačů a stále rozsáhlejšího využínání editorských funkcí World Wide Webu. Mluvčími kyberkultury spojené s kyberpunkem se $\mathrm{v}$ tomto období stala tzv. digitální avantgarda, která propagovala ideje technooptimismu na stánkách časopisů Mondo 2000 a magazínu o kyberkultuře Wierd. Prostřednictvím těchto médií pronikla kyberkultura do povědomí stále širší vrstvy populace a stala se součástí populární kultury.

Další posun v užívání informačních technologií a diferenciací „virtuálních subkultur" v kyberprostoru je spjat s tzv. MySpace generací, která učinila $\mathrm{z}$ internetu diskusní fórum. Mezi reprezentanty těchto kreativních uživatelů internetu patř́ např́íklad zakladatel Facebooku Mark Zuckberg. Uživatelé web 2.0 se ve stále větší míre identifikují s heslem „udělej si sám“, spojují se ve virtuálním prostoru, kde si vytvárejí svou vlastní realitu. Z hlediska kyberantropologie jsou inspirativní např́klad výzkumy věnované vytváření identity na Facebooku, které realizovaly Natalia Rybasová a Radhika Gajjalaová. $\mathrm{K}$ zajímavým výsledkům tohoto výzkumu patří zjištění, že „bíléc středostavovské kultury mají více společného s Afroameričany a Hispánci než s některými př́slušníky vlastní skupiny (Gajjala - Rybas 2007).

\section{VĚDECKÝ VÝZKUM A KONCEPTUALIZACE KYBERKULTURY}

Paralelně s expanzí kyberkultury do každodenního světa narůstal zájem vědců o vědeckou reflexi tohoto sociokulturního fenoménu. Za průkopnickou práci lze označit knihu sociologa Dona Slatera a antropologa Daniela Millera The Internet: An Ethnographic Approach (Internet: Etnografický př́stup, 2000), která představuje první ucelenou antropologickou studii o internetu. Předmětem analýzy bylo zjistit, ,jak se členové určité kultury doma pokoušejí vytvořit transformující se komunikační prostředí, jak mohou sami sebe $\mathrm{v}$ tomto prostředí nalézat a současně se snažit učinit je součástí svého vlastního obrazu" (Slater - Miller 2000, 1). Výzkum byl proveden na ostrově Trinidad v Karibském moři. Zde Miller a Slater zkoumali, jak místní domorodci využívají internet a jeho aplikace (webové stránky, e-mail, diskusní skupiny atd.) v sociálním, politickém, ekonomickém a náboženském kontextu.

Vlivné kyberantropologické výzkumy byly uskutečněny také na Vídeňské univerzitě, kde od roku 1996 Manfred Kremser pořádá série přednášek a seminářů na kyberantropologická témata. Kremser realizoval řadu výzkumů věnovaných analýze afro-karibských a afrických náboženství v kyberprostoru. Podle Kremsera s nástupem kyberprostoru získala tradiční 
africká náboženství zcela nový rozměr, který označil jako „africká digitální diasporická náboženství (Kremser 2003). Kremser svými výzkumy prokázal, že mnohé původní náboženské koncepty a praktiky ztratily pod vlivem moderních informačních technologií svůj lokální charakter a staly se široce dostupnými a globálními ve svém účinku a rozšíření. Na sociokulturní úrovni lze navíc pozorovat, že jak tradiční, tak digitální africké diaspory pod vlivem informačních technologií nemusí nutně nahrazovat původní náboženské praktiky. Spíše mají tendenci reinterpretovat dřivější koncepty podle nových kontextů, přidávat nové dimenze $\mathrm{k}$ tradičním náboženským představám a vytvářet tak paralelní světy náboženských praktik. Kremser ve svých studiích také upozornil na paralely, které lze nalézt mezi virtuálními zážitky, jež přináší fenomén kyberkultury, a tradičními mystickými prožitky spjatými s rituály a náboženskou extází. Princip, který tento typ transcendentních zážitků umožňuje, je podle jeho názoru totožný - je to možnost komunikace jedince s „virtuálními nositeli“ vyššího vědění.

Na Kremserovy práce tvořivým zpơsobem navázali další antropologové, jako např́klad Mark Wilson, jenž uskutečnil kritickou analýzu jedné z nejkomerčnějších webových stránek afro-amerického náboženství - Ifa Foundation. Ve svém výzkumu se zaměřil především na to, zda historické vykořistování afrického lidu a kultury v africké diaspoře pokračuje v kyberprostoru. Inspirativní kyberantropologický výzkum provedl také Kremserův žák Philipp Budka, který ve své etnografické studii zjištoval, jak domorodé skupiny uživají počítačové sítě, jako je internet, www stránky, adresáře a diskusní skupiny. Mezi otázky, na něž se ve svém výzkumu pokusil odpovědět, např́iklad patří: Jak a proč jsou domorodé skupiny reprezentovány na internetu? Kdo je reprezentuje? Při svém výzkumu kombinoval metody zúčastněného pozorování a dotazníkového šetření s etnografickou analýzou textů. Výzkum naznačil, že domorodé skupiny mají tendenci užívat počítačové sítě k šíření informací a komunikaci v rámci jiných sítí a komunit.

Různý úhel pohledu, jaký jednotliví badatelé při výzkumu kyberkultury zaujali, vedl k diferenciaci př́stupů a nejednotnosti v chápání tohoto pojmu. $\mathrm{V}$ raných fázích vývoje kyberkultury, spjaté s rodící se subkulturou hackerů v osmdesátých a na počátku devadesátých let, se zformoval př́stup, který je označován jako „utopický koncept kyberkultury“. Jedná se o optimistickou interpretaci internetu jako kyberprostoru umožňujícího odstranit mocenskou totalitu a rozšírit svobodu člověka novým typem interaktivity a výměny informací. Výrazným reprezentantem tohoto př́stupu ke kyberkultuře byl apologet pozitivní síly nových médií Pierre Lévy, který svou teorii virtuality a vizualizace představil v roce 1997 v knize Cyberculture (česky: Kyberkultura, 2000). Lévy svůj optimismus založil na uznání dvou skutečností: „Za prvé, rostoucí kyberprostor je výsledkem mezinárodního hnutí mladých lidí ochotných kolektivně experimentovat s jinými formami komunikace, než které jim nabízí klasická média. A za druhé, dnes se otevírá nový prostor pro komunikaci, kde záleží jen na nás, zda využijeme jeho nejlepší možnosti, at’ už ekonomicky, politicky, kulturně či lidsky“ (Lévy 2000, s. 9). V souvislosti s narůstající skepsí ve všemocnost síly moderních informačních technologií se zformoval realistický př́istup označovaný jako „informační koncept kyberkultury“. Z této perspektivy, zbavené optimistických vizí, je kyberkultura neutrálně definována jako soubor diskurzů a kulturních praktik, které jsou spojeny s využíváním informačních a komunikačních technologií. V centru výzkumu se ocitla zejména analýza vztahů mezi osobností uživatele počítačů a informačními technologiemi v kontextu kyberprostoru. Takto koncipovaný přístup $\mathrm{k}$ výzkumu kyberkultury klade důraz na analýzu dopadu informačních technologií na lidskou komunikaci a proměnu forem informací ve virtuálním interakčním prostoru. Snaha oddělit od sebe studium médií a výzkum kyberkultury přispěla ke konstituování přístupu, který je označován jako „epistemologický koncept kyberkultury“.

Např́iklad Lev Manovich považuje za předmět teorie médií informační kulturu, zatímco předmětem kyberantropologických studií jsou podle jeho názoru sociální a sítové jevy a procesy, jež jsou s novými komunikačními médii spjaty.

Za inspirativní je možné označit také přístup Davida Listera a okruhu jeho spolupracovníků (Lister et al. 2003). Lister na kyberkulturu pohlíží jako na soubor kulturních praktik, kódů a narací a současně jako na souhrn teoretických epistemologických př́ístupů, analýz a populárních diskurzů kultury, které jsou ovlivněny moderními technologiemi.

$\mathrm{Z}$ této perspektivy kyberkultura představuje sebereflexivní fenomén inspirovaný vlastními naracemi, přičemž teoretická reflexe $\mathrm{z}$ kultury vyrůstá a neustále ji zpětně proměňuje.

Za velice vlivný př́stup ke studiu kyberkultury je možné označit „antropologický koncept kyberkultury“. Z antropologické perspektivy kyberkultura, jež se zrodila jako sekundární produkt moderních informačních technologií, představuje kulturní konstrukt, který má zásadní vliv na lidskou kulturu, sociální interakce, strukturu symbolického světa a sdílený způsob života lidí. Proto antropologové věnují zvýšenou pozornost vzájemnému ovlivňování virtuálního a reálného světa, sociokulturní komunikaci online, kyberprostorovému diskurzu, proměnám identity jedinců v kyberprostoru a důsledkům informačních a počítačových technologií pro život člověka v postmoderní kultuře a společnosti.

Výzkum kyberkultury v současné době zahrnuje široké spektrum prístupů, akcentující zejména informační, sociální, ekonomické, psychologické, technologické, antropologické a epistemologické důsledky vlivu informačních a počítačových technologií na člověka, společnost a kulturu. Přestože se vědci dosud nesjednotili v prŕstupech a konceptech, jejichž prostřednictvím kyberkulturu studují, je evidentní, že tato kategorie představuje relevantní oblast antropologických výzkumů (Macek 2004).

\section{KYBERPROSTOR JAKO PŘEDMĚT VĚDECKÉ A UMĚLECKÉ REFLEXE}

S pojmem kyberkultura je úzce spjat termín kyberprostor 
(„cyberspace“) - virtuální prostor vytvářený prostřednictvím moderních informačních a počítačových technologií. Tento umělý svět symbolů a významů existuje paralelně ke světu reálnému. Antropologický výzkum kyberprostoru zahrnuje pozorování, deskripci, analýzu a interpretaci sociokulturních jevů a procesů, které se odehrávají v interaktivním prostoru vznikajícím prostřednictvím počítačových sítí, internetové infrastruktury a dalšími informačními komunikačními technologiemi (Benedikt 1992, Ebo 1998, Featherstone - Burrows 1995, Hakken 1999, Jones 1997, Jordan 1999, Koepsell 2000). Výzkumným potenciálem rodící se „etnografie kyberprostoru" se zabýval antropolog David Hakken v knize Cyborgs@Cyberspace: An Ethnographer Looks to the Future (Kyborgové@ kyberprostor: Etnografické pohledy do budoucnosti, 1999). Zde vytyčil šest klíčových, hierarchicky uspořádaných otázek vymezujících výzkumné pole etnografie kyberprostoru. Podle Hakkena by měl antropolog při studiu kyberprostoru postupovat podobně, jako postupuje prírodovědec př̀ výzkumu biologické struktury - od substruktur $\mathrm{k}$ makrostruktuře. Proto by měl identifikovat, popsat, analyzovat a interpretovat následující fenomény a procesy:

1. Základní charakteristiky entit nesoucích kyberprostor.

2. Vlastní identity formované těmito entitami. Jak entity konstruují sebe sama v kyberprostoru? Je zde možné pozorovat posun od mechanických $\mathrm{k}$ biologickým metaforám? Jaké kvality přisuzují jiným jedincům v kyberprostoru? Jak se změnily procesy utváření identity?

3. Mikrosociální vztahy vytvářené těmito entitami, jako jsou třeba vztahy mezi přáteli. Jsou vztahy méně skupinové, nebo více orientované na sít? Jaké typy intimních vztahů v kyberprostoru vznikají? Replikují mikrosociální vztahy již existující komunitní vzorce?

4. Mezisociální vztahy vytvářené těmito entitami, jako jsou např́ílad sociální vztahy a kulturní dynamika na úrovni komunity, regionu nebo města. Jak kyberkultura ovlivňuje sociální reprodukci regionů?

5. Makrosociální vztahy vytvářené těmito entitami, jako jsou napríklad vztahy uvnitř národa nebo nadnárodní. Upadá schopnost národů ovlivňovat jejich vlastní reprezentaci v kyberprostoru?

6. Politické a ekonomické struktury, které produkují a reprodukují entity kyberprostoru, jimiž jsou zpětně limitovány (Hakken 1999, 7-11).

Tyto otázky mají prostřednictvím konkrétního popisu a analýzy výše popsaných úrovní sociální interakce v kyberprostoru vytyčit další relevantní otázky a určit tak další směr výzkumu. Navíc umožní zjistit, zda a jak intenzivně ve studované společnosti proběhla „počítačová revoluce“, pro niž je charakteristický posun od marginalizace a mechanické výroby směrem $\mathrm{k}$ utváření nového typu sociální formace, založené na používání moderních informačních technologií.

Pojem kyberprostor se dříve než ve vědě prosadil v krásné literatuře, kam jej poprvé uvedl americký spisovatel William Ford Gibson (narozen 1948) ve své povídce „Jak vypálit chrom" (1982) a knize Neuromancer (Gibson 1984). Podle Gibsona kyberprostor představuje počítačový trojrozměrný svět, ve kterém se data uživatelům sítí jeví jako geometrické struktury a virtuální realita. Někteř́ hrdinové jeho románu jsou schopni vstoupit do tohoto digitálního prostoru a zažívat v něm různá dobrodružství. Gibson se při psaní svých knih inspiroval stylem a drsnou poetikou detektivek amerického spisovatele Raymonda Chandlera (1888-1959), kterou spojoval s žánrem science fiction. Osobitou směsici metafyziky a technické estetiky virtuálního světa výrazně uplatnil také v roce 1987 v románě Count Zero (Bod nula) a poté v roce 1989 v knize Mona Lisa Overdrive (česky Zběsilá jízda, 1998). Gibson svými knihami přispěl k etablování témat, jež kombinují razantní vypravěčství drsných a akčních př́běhủ se zájmem o vědecké technologie umožňující zásah do lidského těla a mysli. Z tohoto hlediska lze Gibsona označit za průkopníka hnutí kyberpunk, jehož představitelé, inspirováni virtuálním počítačovým světem, vytvořili osobitý literární a umělecký žánr vědecké fantastiky.

Sugestivnost virtuální reality a vědecko-fantastických př́běhů, jež se odehrávají v kyberprostoru, originálním způsobem využili jako ústř̌ední téma $\mathrm{v}$ kultovní filmové trilogii The Matrix (Matrix) američtí režiséři - bratř̌ Andy a Larry Wachowští. Matrix zde představuje rozsáhlý počítačový systém, na který jsou připojeni lidé, žijící v něm svůj virtuální život. Jejich základní funkcí je dodávat strojům, jež převzaly nadvládu na planetěe, energii svých těl. Zotročení lidé si ale tento úděl neuvědomují, nebot je jim do mozku promítána virtuální realita. Filmová trilogie Matrix originálním způsobem zpracovala velké postmoderní téma - paradoxní dualitu vztahu mezi člověkem a umělou inteligencí.

\section{KYBERPUNK}

Světem počítačủ a informačních technologií bylo výrazně ovlivněno také umělecké hnutí kyberpunk („,cyberpunk“). Kyberpunk vznikl jako literární směr, který se na počátku osmdesátých let 20. století odklonil od žánru klasické science fiction (Sterling 1986, Cavallaro 2000).

$\mathrm{V}$ průběhu následujících let se dále profiloval jako svébytná teoretická, filozofická a umělecká reflexe světa, vystupující nejen $\mathrm{v}$ podobě literárních děl, ale také prostřednictvím divadelních a hudebních performancí. Literární představitelé amerického kyberpunku - William Ford Gibson, Lewis Shiner (narozen 1950), Michael Bruce Sterling (narozen 1954), John Patrick Shirley (narozen 1953), Pat Cadiganová (narozena 1953) a Rudolf von Bitter Rucker (narozen 1946) provedli ve svých knihách originální syntézu metafyziky, antropologie, technizované estetiky a science fiction, založenou na príbězích o potenciálním spojení umělých technologií s lidskou biologií a virtuální realitou.

Mezi preferovaná témata kyberpunku patří interakce lidí s roboty, androidy a kyborgy disponujícími umělou inteligencí. Hrdinové kyberpunkových př́iběhů, často spjatí se světem hackerů, se pohybují $\mathrm{v}$ přetechnizovaném světě blízké budoucnosti, ve kterém hrají významnou roli informační technologie, implantáty fyzické i mentální povahy, biotech- 
nologie, nanotechnologie a kyberprostor. Dějové dynamiky je dosaženo využitím detektivních zápletek a akčních scén, jež se odehrávají v nihilistické, undergroundové atmosfére a cynickém prostředí, v němž často vládne zločin, drogy, průmyslová mafie a nadnárodní společnosti. V tomto kontextu se utvárí poznání, že autenticitu lze generovat synteticky a rozdíly mezi kyberprostorem a skutečnou realitou, biologií a technologií, člověkem a umělou inteligencí jsou nejen relativní, ale i fascinující.

Kyberpunkový svět uvedl na plátna kin v roce 1982 britský režisér Ridley Scott (narozen 1937) v kultovním snímku Blade Runner, inspirovaném románem amerického spisovatele Philipa Kindreda Dicka (1928-1982) Do Androids Dream of Electric Sheep? (1968, česky: Blade Runner: Sní androidi o elektrických ovečkách? Praha: Argo, 2004).

Tento film, odehrávající se v blízké budoucnosti, se stal základem pro vizuální ikonografii kyberpunku. Ridley Scott zde prostřednictvím skvělé výpravy, rafinované režie a působivé hudby prezentuje Los Angeles jako odcizené, depresivní a neustále deštivé město, $\mathrm{v}$ němž se dekadentně a absurdně prolínají různé kultury a národy. Úkolem hlavního hrdiny, osamělého detektiva Ricka Deckarda, je pátrat po androidech, kteří uprchli na Zemi z jim vyhrazených pracovních kolonií na jiných planetách. Existenciální hloubka filmu vyrůstá ze zpochybnění hranic, jež oddělují člověka a androidy. Ti totiž v morfologických i mentálních parametrech vykazují obdobné vlastnosti jako lidé a jejich útěk je bojem o právo na lidský život. Dilema hlavní postavy vyrůstá ze zjištění, že není schopen dále androidy ničit, když dokáží být více lidští než sám člověk. Prezentovaný problém vztahu člověka k umělé inteligenci, která je sice lidským dílem, ale zápasí o vlastní identitu a právo na autentický život, se stalo významným tématem kyberpunkových knih a filmů, a dokonce ovlivnilo úvahy některých antropologů a filozofů nad specifikou lidského rodu. Originálním způsobem uplatnila koncept kyborga, který $\mathrm{v}$ dílech autorů science fiction vystupuje jako hybridní spojení stroje a lidského organismu, americká bioložka, feministka a filozofka Donna Harawayová (narozena 1944). Ve svém slavném eseji A Cyborg Manifesto: Science, Technology, and Socialist-Feminism in the Late Twentieth Century (Manifest Kyborgů: Věda, technologie a socialistický feminismus ke konci dvacátého století, 1985)využila metaforu kyborga, aby zpochybnila hranice oddělující od sebe zvírata, lidi a stroje (Haraway1991, 149-181). Z perspektivy kyborga, do níž se Harawayová s lehkou ironií a nadsázkou stylizuje, ztrácejí smysl a objektivní platnost takové distinkční kategorie, jako je „pohlaví/gender“, „člověk/stroj“, „přirozené/umělé“, „autentické/ neautentické“, „příroda/kultura“. V identitě kyborga, která je založena na propojení živého těla a umělých technologických extenzí, je zpochybněn pohlavní dualismus a narušena totalita tradičních diskursivních hranic.

Pro konstituování kyberpunku byl klíčový rok 1983. Tehdy došlo k osobním setkáním kyberpunkových spisovatelů Williama Gibsona, Bruce Sterlinga, Lewise Shinera a Rudyho Ruckera a americký spisovatel Bruce Bethke (narozen 1955) vydal povídku Cyberpunk (Kyberpunk, 1983), která dala celému hnutí jméno. V roce 1983 kanadský režisér David Paul Cronenberg (narozen 1943) natočil film Videodrome, vyjadřující kyberpunkové vize virtuální a mediální reality, a nakladatelství Semiotext(e) vydalo anglický překlad filozofických esejů francouzského sociologa Jeana Baudrillarda (1929-2007) Simulacra and Simulations (Simulakra a simulace), které z tohoto teoretika postmoderny učinily hlavního filozofa kyberkultury (Baudrillard 1983).

Baudrillard ovlivnil teoretiky kyberkultury a reprezentanty hnutí kyberpunku zejména svou teorií „simulakra“ jako zprostředkované simulace skutečnosti. Tuto koncepci představil v eseji Lordre des simulacres (Řády simulakra), která je součástí knihy Léchange symbolique et la mort (Symbolická směna a smrt) (Baudrillard 1976). Podle Baudrillarda se v dějinách lidské kultury postupně zformovaly tři řády simulakra: (1) preindustriální simulakra, (2) industriální simulakra a (3) čistá simulakra. Později, v knize La transparence du mal: Essai sur les phénomèmes extrêmes (Transparence zla: Esej o extrémních fenoménech) tuto typologii dále rozširril a představil zde fraktální (virální) simulakra (Baudrillard 1990). Podle Baudrillarda simulakra představují třídu znaků, které vystupují jako kopie postrádající originál. Jejich cílem je předstírat a klamat. Jedná se o zobrazení, která se primárně oddávají hře, jejíž pravidla vyžadují simulovat vztah k reálnému předobrazu. Z hlediska kyberkultury jsou podstatná především čistá a fraktální simulakra. Čistá simulakra představují specifickou znakovou vrstvu a sémiotický text, který předstihuje a nakonec zcela pohlcuje realitu. Součástí lidského života se tak stává „hyperreálná skutečnost“, která je „reálnější než reálné“. Zrození hyperreality, jež funguje jako „vyretušovaná skutečnost“, je spjato zejména s mediální simulací, kterou umožnily prostředky masové komunikace a moderní informační technologie. Absolutní falzifikaci reálného světa reprezentují fraktální simulakra. Tato třída znaků již nemá vztah k žádné realitě a jako specifický jev sui generis a „nekontrolovatelná metonymie" podporuje neurčitost, reverzibilitu a fragmentárnost. Hyperrealita je úzce spjata s procesy simulace. Tímto pojmem se Baudrillard pokouší charakterizovat strukturu moderních systémů, které ztratily vztah k realitě a nahrazují ji znaky nebo obrazy. Vztah k reálnému světu se utvárí uvnitř systému hyperreality, prostřednictvím kódů, modelů a simulací, jež tento systém sám konstruoval. Proces simulace je proto omezen na reduplikaci, která substituuje realitu samotnými znaky reality, jež však nelze dešifrovat. Výsledkem simulace je tak zhroucení vztahu mezi znakem a objektem. Podle Baudrillarda má simulace čtyři hlavní důsledky.

Za prvé smazává rozdíl mezi pravdou a falší vede $\mathrm{k}$ neurčitosti. Za druhé programuje skutečnost, která je vždy předem vepsaná do kódu, vede ke zvýšení určenosti.

Za třetí programuje zkušenost a očekávání, a tak funguje jako prostředek integrace a nástroj sociální kontroly.

Za čtvrté vytváří jak emotivně vypjatou zkušenost, zesílenou vstupem ze skutečného do hyperreálného (sémiotická „estetická halucinace reality“), tak stavy psychického utlumení, vyvolané tím, jak simulace „neutralizuje“ symbolické vztahy, významy, vášně a možnosti (Merrin 2010, 217-219; Horyna 
- Půtová 2009, 3907). Fenomén hyperreality fascinoval jak autory science fiction a kyberpunkové literatury, tak reprezentanty kritického proudu mediálních a kulturálních studií, kteří učinili prredmětem svých výzkumů dopad symbolických obsahů šířených masmédii na způsob lidského života. Dostatečně výmluvná je $\mathrm{z}$ tohoto hlediska jedna ze scén filmu Matrix, ve které hlavní hrdina Neo otevírá Baudrillardovu knihu Simulakra a simulace...

Význačným mezníkem vývoje kyberpukového hnutí byl rok 1984, kdy americký novinář Steven Levy (narozen 1951) vydal první knihu věnovanou subkultuře hackerů - Hackeři (Levy 1984). V této době byl založen pověstný haeckerský klub Legion of Doom a pojem hacker pronikl do každodenního jazyka. Ve druhé polovině osmdesátých let pokračovala expanze kyberpunku, který byl stále více vnímán jako součást postmoderní kultury. $\mathrm{Na}$ počátku devadesátých let se zformovala druhá vlna kyberpunku, jejíž představitelé, jako např́ílad Neal Town Stephenson (narozen 1959), rozšiŕíili spektrum tradičních námětů a témat o dimenzi humoru. Svébytnou součástí kyberpunkových děl se v první polovině devadesátých let stalo také téma kybernetického a virtuálního sexu. Např́klad v roce 1992 začal vycházet časopis Future Sex, $\mathrm{v}$ jehož článcích se setkáváme s pokusy literárně spojit erotiku s kyberkulturou. V průběhu devadesátých let byla expanze kyberpunku do různých oblastí zábavy doprovázena určitým stupněm komercializace kyberpunkových produktů. V současné době je možné sledovat nárůst zájmu společenských věd o vědeckou reflexi kyberpunkového hnutí a jeho důsledků pro uměleckou tvorbu, životní styl a trávení volného času v podmínkách postmoderní kultury.

Z antropologického hlediska představuje fenomén kyberpunku významnou tematickou oblast výzkumů kyberantropologie. $\mathrm{V}$ průběhu své existence představitelé kyberpunku vytvořili řadu děl, v nichž byly formulovány nadčasové filozofické, antropologické a existenciální otázky. Například ve světě kyberpunku získala tradiční filozofická dichotomie „člověk versus zviřre“ nový antropologický rozměr, který lze vyjádřit dichotomií „člověk versus umělá inteligence“. Jinými slovy, z kyberantropologické perspektivy se neklade otázka, čím se člověk liší od ostatních živočichů, ale čím se liší od umělé inteligence, o jejíž vytvoření lidstvo usiluje. Na půdě kyberpun$\mathrm{ku}, \mathrm{v}$ rovině umělecké nadsázky, tak byl anticipován problém vztahu člověka ke stroji, který jednou bude disponovat stejným kognitivním potenciálem jako př́ílušníci lidského rodu.

\section{LITERATURA}

Aronowitz, Stanley, et. al. (1996): Technoscience and Cyberculture. New York: Routledge.

Balsamo, Anne, M. (1996): Technologies of the Gendered Body: Reading Cyborg Women. Durham: Duke University Press.

Baudrillard, Jean (1983): Simulacra and Simulation. New York: Semiotext(e).

Baudrillard, Jean (1993): Symbolic Exchange and Death. London: Sage Publications Ltd.

Baudrillard, Jean (1993): The Trasparency of Evil: Essays on Extreme Phenomena. London: Verso.

Bell, David (2001): An Introduction to Cyberculture. New York: Routledge.
Benedikt, Michael, ed. (1992): Cyberspace: First Steps. Cambridge, Massachusetts: MIT Press.

Ebo, Bosah, L. (1998). Cyberghetto or Cybertopia?: Race, Class, and Gender on the Internet. Westport: Praeger.

Castells, Manuel (1996): The Information Age. Economy, Society and Culture, Vol. I: The Rise of the Network Society. Oxford: Blackwell Publishers.

Castells, Manuel (1997): The Information Age. Economy, Society and Culture, Vol. II: The Power of Identity. Oxford: Blackwell Publishers.

Castells, Manuel (1998): The Information Age. Economy, Society and Culture, Vol. III: End of Millennium. Oxford: Blackwell Publishers.

Cavallaro, Dani (2000): Cyberpunk and Cyberculture: Science Fiction and the Work of William Gibbon. London: Athlone Press.

Dick, Philip Kindred (1968): Do Androids Dream of Electric Sheep? New York: Doubleday.

Escobar, Arturo (1994): Welcome to Cyberia. Notes on the Anthropology of Cyberculture. Current Anthropology, 35(3), 211-231.

Escobar, Arturo (1995): Encountering Development. The Making and Unmaking of the Third World. Princeton, New Jersey: Princeton University Press.

Featherstone, Mike - Burrows, Roger, eds. (1995): Cyberspace, Cyberbodies, Cyberpunk: Cultures of Technological Embodiment. London: SAGE Publications

Featherstone, Mike, ed. (1990): Global Culture: Nationalism, Globalization and Modernity. London: SAGE Publications.

Fox, Richard, ed. (1991): Recapturing Anthropology: Working in the Present. Santa Fe: School of American Research Press.

Gajjala, Radhika - Rybas, Natalia (2007): Developing Cyberethnographic Research Methods for Understanding Digitally Mediated Identities. Forum Qualitative Social Research, 8(3), 1-33.

Gibson, William (1984): Neuromancer. New York: Ace Books.

Gibson, William (1986): Count Zero. New York: Ace Books.

Gibson, William (1998): Zběsilá jízda. Brno: Návrat.

Graham, Gordon (1999): The Internet: A Philosophical Inquiry. London: Routledge.

Hafner, Katie - Markoff, John (1995): Cyberpunk: Outlaws and Hackers on the Computer Frontier. New York: Simon \& Schuster.

Hamelink, Cees (1997): New Information and Communication Technologies, Social Development and Cultural Change. Geneva: UNRISD, Discussion Paper 86.

Hakken, David (1999): CYBORGS@CYBERSPACE: An Ethnographer Looks to the Future. London: Routledge.

Haraway, Donna (1991): Simians, Cyborgs and Women: The Reinvention of Nature. New York: Routledge, 149-181.

Heap, Nick - Thomas, Ray - Einon, Geoff - Mason, Robin - Mackay, Hughie, eds. (1995): Information Technology and Society. London: SAGE Publications.

Horyna, Břetislav - Půtová, Barbora (2010): Simulace (simulakrum). In: Malina, Jaroslav, ed., Antropologický slovník aneb co by mohl o člověku vědět každý člověk. Brno: Akademické nakladatelství CERM, 3907.

Jones, Steve, ed. (1997): Virtual Culture: Identity and Communication in Cybersociety. London: SAGE Publications.

Jordan, Tim (1999): Cyberpower: The Culture and Politics of Cyberspace and the Internet. London: Routledge.

Klepper, Martin - Schneck, Ernst-Peter - Mayer, Ruth (1996). Hyperkultur: Zur Fiktion des Computerzeitalters. Berlin - New York: Walter de Gruyter.

Koepsell, David, R. (2000): The Ontology of Cyberspace: Philosophy, Law, and the Future of Intellectual Property. Chicago: Open Court.

Kolko, Beth, E. - Nakamura, Lisa - Rodman, Gilbert, B., eds. (2000): Race in Cyberspace. New York: Routledge.

Kremser, Manfred (2003): Afrikas Digitale Diaspora - Selbstrepräsentation vs. Fremdrepräsentation im Internet. In: Zips, Werner, ed., Afrikanische Diaspora. Out of Africa - Into New Worlds. Reihe Afrika und ihre Diaspora. Bd. 1. Münster: LIT.

Lévy, Pierre (1997): Collective Intelligence: Mankind's Emerging World in Cyberspace. New York: Plenum Press.

Lévy, Pierre (2000): Kyberkultura. Praha: Karolinum.

Levy, Steven (1984): Hackers: Heroes of the Computer Revolution. New York: Garden City. 
Lister, David et al (2003): New Media: A Critical Introduction. London: Routledge.

Ludlow, Peter, ed. (1996): High Noon on the Electronic Frontier. Conceptual Issues in Cyberspace. Cambridge, Massachusetts: MIT Press.

Lyon, David (1988): The Information Society: Issues and Illusions. Oxford: Polity Press.

Macek, Jakub (2004): Koncept rané kyberkultury. In: Volek, Jaromír Binková, Pavlína, ed., Média a realita. Brno: Fakulta sociálních studií Masarykovy univerzity, 35-65.

Merrin, William (2010): Spekulace ke smrti: Teoretické násilí Jeana Baudrillarda. In: Edwards, Tim, ed., Kulturální studie. Praha: Portál, 217-219.

Miller, Daniel - Slater, Don (2000): The Internet: An Ethnographic Approach. Oxford: Berg.

Rheingold, Howard (1991): Virtual Reality. New York: Summit Books.

Rheingold, Howard (1994): The Virtual Community: Homesteading on the Electronic Frontier. New York: HarperPerennial.

Schroeder, Ralph (1996): Possible Worlds. The Social Dynamic of Virtual Reality Technology. Boulder, Colorado: Westview Press.

Shields, Rob, ed. (1996): Cultures of Internet: Virtual Spaces, Real Histories, Living Bodies. London: SAGE Publications.

Soukup, Martin (2010): Biokulturologie: evoluce člověka a kultury, Praha: Unie Comenius.

Sterling Bruce, ed. (1986) Mirrorshades: The Cyberpunk Anthology. New York: Arbor House.

Turkle, Sherry (1984): The Second Self: Computers and the Human Spirit. London: Granada.

Turkle, Sherry (1996): Life on the Screen: Identity in the Age of the Internet. London: Weidenfeld \& Nicolson.

Webster, Frank (1995): Theories of the Information Society. London: Routledge.
AUTOR

Soukup, Václav (31. 8. 1957, Mariánské Lázně), český kulturolog a antropolog působící na Filozofické fakultě Univerzity Karlovy v Praze, kde přednáší základy sociální a kulturní antropologie, kulturologie a paleoantropologie. Patř́ k zakladatelům interdisciplinárně koncipovaného studijního oboru kulturologie a průkopníkům biokulturologie. Je autorem řady odborných článkủ a vědeckých monografí věnovaných dějinám antropologického myšlení. Jeho kniha Dějiny antropologie (2004) byla oceněna Cenou rektora Univerzity Karlovy jako nejlepší publikace v oblasti společenských věd za rok 2004. Za svůj dlouhodobý př́nos k rozvoji antropologie obdržel v roce 2009 na Masarykově univerzitě v Brně Cenu Vojtěcha Suka. V roce 2011 vyjde v nakladatelství Portál jeho kniha Antropologie: teorie člověka a kultury, jež navazuje na vědeckou monografii Přehled antropologických teorií kultury (2000). Jedná se o rozsáhlé antropologické kompendium, které komplexně seznamuje s předmětem, metodami, dějinami a základními oblastmi antropologického výzkumu člověka a kultury. V současné době dokončuje práce na knize Základy biokulturologie, jejímž cílem je rekonstruovat evoluci člověka a kultury $\mathrm{z}$ multidimenzionální perspektivy přírodních a společenských věd.

Kontakt: Kontakt: PhDr. Václav Soukup, CSc., Katedra teorie kultury (kulturologie) Filozofické fakulty Univerzity Karlovy v Praze, Celetná 20, 11000 Praha 1, e-mail: Vaclav.Soukup@ff.cuni.cz. 